\title{
Modeling Chinese Domestic Cereal Flow due to Stock and Economic Gradient
}

\author{
Toshiaki Ichinose ${ }^{1,2} \& \mathrm{Kai}_{\mathrm{Liu}}^{3}$ \\ ${ }^{1}$ Center for Social and Environmental Systems Research, National Institute for Environmental Studies, Tsukuba City, \\ Japan \\ ${ }^{2}$ Graduate School of Environmental Studies, Nagoya University, Nagoya City, Japan \\ ${ }^{3}$ Doctoral Program in Geoenvironmental Science, University of Tsukuba, Tsukuba City, Japan \\ Correspondence: Toshiaki Ichinose, Center for Social and Environmental Systems Research, National Institute for \\ Environmental Studies, 16-2 Onogawa, Tsukuba City, Ibaraki, 305-8506 Japan.
}

Received: June 23, 2017

Accepted: August 8, $2017 \quad$ Available online: September 25, 2017

doi:10.11114/ijsss.v5i10.2508

URL: https://doi.org/10.11114/ijsss.v5i10.2508

\begin{abstract}
To evaluate vulnerability of cereal transportation and stocks estimated from the land use and supply-demand on cereal in China, two types of numerical models (Non-market type and Market type) were developed and applied to this topic. Input data were $20 \mathrm{~km}$-cell base. Target year was around 1995. In case of no cereal transportation, severe cereal shortage appeared in urban regions. In the non-market-type model, cereal was transported from grid-cells with positive cereal stocks to grid-cells with the negative in proportion to the ratio of their GDP. In the market-type model, each grid cell absorbed cereal from surrounding cells in proportion to its GDP (economic potential). In the non-market-type model, regional imbalances of cereal stocks were decreased by the cereal transportation. However, the result in the market-type model showed some risk of decreasing cereal stocks in hinterlands of productive regions and in urban regions far from productive regions, especially coastal zone in the south China, because a quick accumulation of cereal in the coastal municipalities enlarged such regional imbalances.
\end{abstract}

Keywords: cereal balance, cereal transportation, numerical model, market system, economic potential

\section{Introduction}

The balance between food supply and demand in China would make a great influence on global food security. Since the publication of Brown's controversial book (Brown, 1995) with its pessimistic view, the food self-sufficiency of China has become a controversial issue. It is concerned with how to transform and sustain the grain producing regions in the face of China's rapid economic growth. Otsubo et al. (2002) produced 20-km grid maps of population in China (1990) by distributing population at the county level to each cell with the help of improved DMSP/OLS (Defense Meteorological Satellite Program / Operational Linescan System) Stable Light Images. Based on these maps etc. they produced maps of the grain yield and consumption in China. They show the national total of all grains yields exceeded that of all grains consumptions in 1995 but there were so many locations where grain consumptions exceeded grain yield.

Xiao and Wang (1999), Xiao (1997) analyzed land use change of China in view point of food production and show that the rapid urbanization since 1980s gave some impact on the food production through the decreasing of cultivated area. After the system of market economy in China was introduced, some food was inputted into the market as traded materials and food started moving to the place where it was sold in higher price. The term 'food miles' refers to the distance food travels from the location where it is grown to the location where it is consumed and this distance has been steadily increasing over the last fifty years. Grebitus et al. (2013) investigated how consumers' willingness to pay (WTP) for food varies by the number of miles the food traveled and the drivers of consumer preferences towards food miles. Distance of transportation has several impacts that can be related for example to freshness, the environment, taste, health and local economy. They show that the average WTP is falling in distance traveled. Zepeda and Deal (2009) studied on consumer motives for preferring local foods. Preferences for sustainable foods and food miles are affected by consumers' health concerns and environmental concerns perceived social influences (Siriex et al. 2008). It is also better for the environment due to shorter distances of transportation and less energy usage during production and 
transportation, because increasing food miles may lead to higher usage of fossil fuels that are required for transportation.

Vanek and Sun (2008) show that the use of rail for food transportation can reduce life cycle energy consumption compared to truck but the increase in perishability of food products can undercut the energy savings, and in some circumstances, the use of inter-modal rail can be environmentally superior to carload freight for delivery. In China, approximately 70 million $\mathrm{t}$ of food was transported by rail and 20 million $\mathrm{t}$ by ship in 1998 (China Statistical Yearbook). Detail statistic of food transportation by truck is missing but seems to be limited for short-range transportation.

Wang et al. (2002) created a 2-km grid map of potential arable land in China in taking into consideration natural conditions, such as topographical, climatic, soil and land-use properties. They show a large area of convertible arable land exists in northern China, while there is a small area of convertible land in the south. They also show some areas in the middle-south China which are considered to be unsuitable for cultivation but have been cultivated. In China's domestic markets we can see the structure shifting from the southern district to the northern districts as a result of the emerging differentiation of food shortage and regional overproduction (Zhang, 2000).

In this research, the authors aimed to evaluate the vulnerability of cereal stocks and the flow of cereal (defined as rice, wheat and maize by the following reason) in China as estimated from the current land use and supply-and-demand of cereal. The authors also oriented to determine the pressure of land use change on cereal stocks. The authors regarded cereal transportation as reflecting not only supply-and-demand but also the economic gradient, i.e., the energy and cost of transportation. The major factor influencing the energy and cost of transportation is distance. The authors expect that patterns of cereal transportation introduced by their numerical models referring to current supply-and-demand of cereal and the economic gradient will contribute to comparisons with observed patterns and to discussions on the sustainability of supply-and-demand. In China approximately $400 \mathrm{~kg}$ of cereal per capita was consumed in 1996 (China Statistical Yearbook). It contains feed, seed and processing etc. The production of the three major grains (wheat, rice, maize) accounts for $96 \%$ of the total cereal grain (production, stock and export) on the FAO-STAT Chinese food-balance sheet in 2001. The authors, therefore, defined the concept of 'cereal' discussed in this research as these three major grains.

To estimate cereal stocks in the middle-south China, the authors developed two types of model. A 20 -km-grid dataset (Otsubo et al., 2002) was used as the input data, and the numerical simulations were initialized with data from 1995. Parameterization of the models was performed considering the stability of computing: all input data were scaled from 0 to 9 (no dimension, Table 1); both cereal production and cereal consumption shared the same scaling; and 20-km distances were scaled to 1 (no dimension).

Table 1. Scaling of supply-and-demand of cereal per grid cell

\begin{tabular}{cc}
\hline Grade & Range $(\mathrm{kg} /$ year $)$ \\
\hline 0 & $0 \sim 40000$ \\
1 & $40000 \sim 80000$ \\
2 & $80000 \sim 120000$ \\
3 & $120000 \sim 160000$ \\
4 & $160000 \sim 200000$ \\
5 & $200000 \sim 240000$ \\
6 & $240000 \sim 280000$ \\
7 & $280000 \sim 320000$ \\
8 & $320000 \sim 360000$ \\
9 & $360000 \sim$ \\
\hline
\end{tabular}

\section{Structures of the Models}

\subsection{Non-market-type Model}

In this model (depicted schematically in Figure 1), cereal is transported proportionally to the ratio of GDP (shown in eq. 4) from grid cells with excess cereal to grid cells with a shortage of cereal. The basic equations of the model are:

$$
\begin{gathered}
d S_{a}=\left(P_{a}-C_{a}+I T_{a}-O T_{a}\right) \mathrm{dt} \\
I T_{a}=\Sigma_{\mathrm{b}} O_{b a} \\
O T_{a}=\Sigma_{\mathrm{b}} O_{a b} \\
O_{a b}=\mathrm{k}\left(G_{b} / G_{a}\right)\left(S_{a}-S_{b}\right) / R_{a b}
\end{gathered}
$$

where $S_{a}$ is cereal stock in grid cell a, $S_{b}$ is cereal stock in grid cell b, $P_{a}$ is annual cereal production in grid cell a, $C_{a}$ is annual cereal consumption in grid cell a, $I T_{a}$ is annual cereal inflow to grid cell a, $O T_{a}$ is annual cereal outflow from grid cell a, $G_{a}$ is GDP in grid cell a (GDP density), $G_{b}$ is GDP in grid cell b (GDP density), $R_{a b}$ is distance between grid cell a 
and grid cell b, $O_{a b}$ is cereal outflow from grid cell a to grid cell $\mathrm{b}$, $\mathrm{dt}$ is set to $0.1, \mathrm{k}$ is a constant with a dimension of velocity (Cereal transportation intensity coefficient [TIC]: Cereal transportation per dt).

In the case where $\left(S_{a}-S_{b}\right)<0, O_{a b}$ is assumed to be 0 . In other words, cereal is not transported from grid cell a to grid cell b.

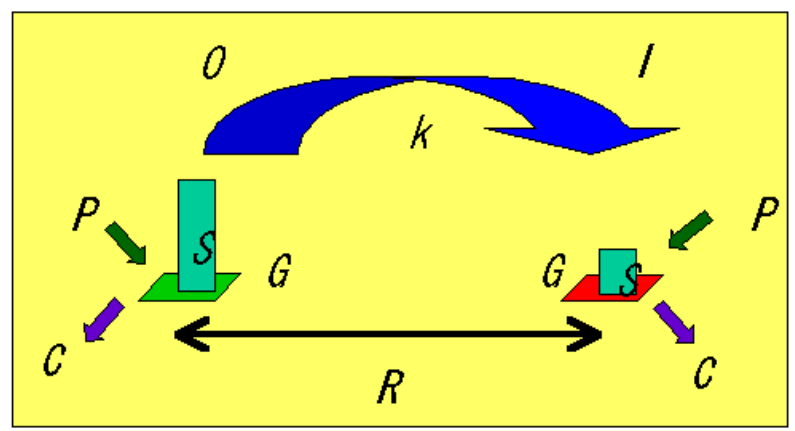

Figure 1. Structure of non-market-type model

Note: $S$ : Cereal stock in a grid cell, $P$ : Annual cereal production in a grid cell, $C$ : Annual cereal consumption in a grid cell, $I$ : Annual cereal inflow to a grid cell, $O$ : Annual cereal outflow from a grid cell, $G$ : GDP in a grid cell (GDP density), $R$ : Distance between grid cells, k: A constant with a dimension of velocity (Cereal transportation intensity coefficient [TIC]: Cereal transportation per dt).

\subsection{Market-type Model}

In this model, the potential absorption of cereal into a grid cell is defined in proportion to the GDP in that grid cell. When the pattern of cereal transportation is decided in this way, according to market theory, it is possible for cereal to be transported from a region of cereal shortage to a region of cereal excess. To resolve such imbalances, adjustments must be made in cereal production and cereal consumption (including emigration of people from that grid cell); therefore, the authors consider that this model better expresses the actual situation in China. The basic equations of this model are generally the same as those of the non-market-type model, but the definitions of $I T_{a}$ and $O T_{a}$ are different.

When the potential inflow of cereal to grid cell a $\left(I T_{a}\right)$ is defined as equation 5 using population $\left(N_{a}\right)$ and $\operatorname{GDP}\left(G_{a}\right)$ in grid cell $\mathrm{a}$, the inflow of cereal from grid cell $\mathrm{b}$ to a $\left(I_{a b}\right)$ is described as equation 6 with probability density function, $f$. The potential to collect cereal in a grid cell is the refore regarded as proportional to the population and the GDP.

$$
\begin{gathered}
I T_{a}=\mathrm{p} N_{a} G_{a} / \mathrm{G}_{0} \\
I_{a b}=I T_{a} f\left(R_{a b}\right) / \int_{\mathrm{b}} f\left(R_{a b}\right) d R_{a b}
\end{gathered}
$$

pis the potential absorption of cereal per dt per capita (Cereal absorption coefficient [CAC], i.e., cereal demand per dt per capita). $\mathrm{G}_{0}$ is the spatial mean of GDP. $R_{a b}$ is the distance between grid cell a and grid cell b. $G_{a} / \mathrm{G}_{0}$ is regarded as relative economic potential.

Equation 6 is introduced because one of the concepts of this model is that a grid cell with large GDP collects cereal widely and thinly, while a grid cell with small GDP collects only from nearby grid cells. The cereal budget per dt per grid cell is the same as the non-market-type model. Variability per dt is adjustable by $\mathrm{p}$.

No inflow is assumed to occur to grid cell a if the cereal stock of grid cell b is not positive (Eq. 7). On the other hand, the outflow from grid cell a, $O T_{a}$, is defined as the sum of inflow from grid cell a to all other grid cells and is expressed as equation 8 .

$$
\begin{gathered}
I_{a b}=0 \text { in the case of } S_{b} \leqq 0 \\
O T_{a}=\Sigma_{\mathrm{b}} I_{b a}
\end{gathered}
$$

The probability density function $f$ has the characteristics shown in equation 9 , where $R$ is the distance from grid cell a.

$$
f(R)=1 / G_{a} \exp \left(-R / G_{a}\right)
$$

\section{Results and Discussion}

\subsection{Behavior of the Models for a Model-island}

To evaluate the basic functions of the models before applying to China, the authors applied the two models to a pseudo island (a model-island) with a size of around $360 \mathrm{~km}$ by $360 \mathrm{~km}$. Land use (Figure 2), population density, GDP density, 
and cereal consumption and production (Figure 3) are arbitrarily assumed for this island. This island is a perfect closed system, and there is no export or import of cereal. Population and GDP are assumed to be in proportion to cereal consumption. The initial value of cereal stocks was fixed to 10 in all grid cells on the island.

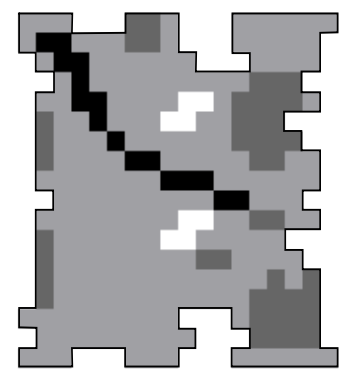

Figure 2. Land use in a model-island

Note: White: Water, Light gray: Productive region, Dark gray: Urban, Black: Mountains.
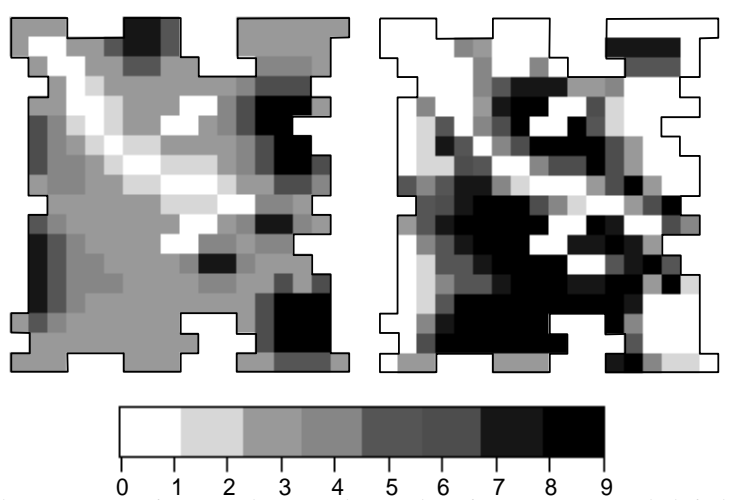

Figure 3. Cereal consumption and cereal production on a model-island (10 grades)

In the non-market-type model, the computed result at time-step 20 for different TICs is shown in Figure 4 . In the case where there was no cereal transportation, severe cereal shortages occurred in urban areas. As the TIC increased, the cereal shortages disappeared followed by decreasing cereal stocks in productive areas. In the case of a TIC of 0.03 , cereal concentrated rapidly into urban areas and cereal stocks became stable at around 10 in the margins of productive areas and around 15 in their centers.

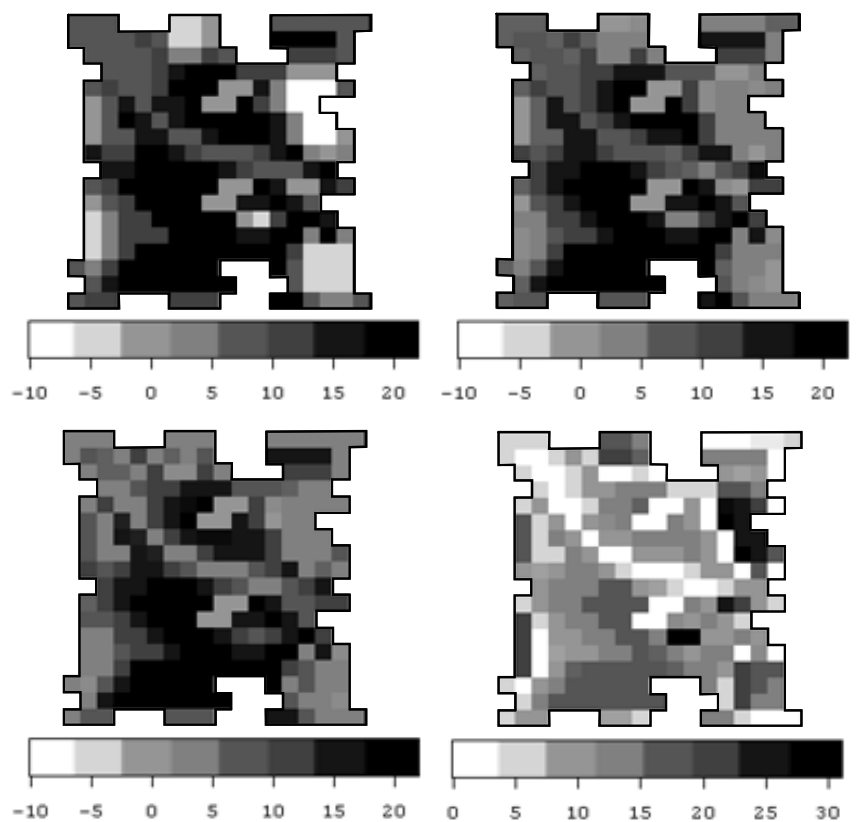

Figure 4. Cereal stocks in a model-island (Non-market-type model: at time-step 20)

Note: The margin cells were not included in the computation. No transportation (Upper left), Transportation Intensity Coefficient: 0.003 (Upper right), Transportation Intensity Coefficient: 0.01 (Lower left), Transportation Intensity 


\section{Coefficient: 0.03 (Lower right).}

The probability density function $f$ in the market-type model expresses the decreasing cereal absorption potential as the distance from grid cell increases. Values relative to 1.0, the absorption potential for a self-referential grid cell, are shown in Table 2. A grid cell with a GDP density of 1.0 collects cereal from grid cells located up to 2 grid cells away, while a grid cell with a GDP density of 9.0 collects cereal from up to 9 grid cells away.

Table 2. The influence of the economic potential at absorbing grid cell a $\left(G_{a}\right)$ to decrease the ratio of cereal absorption potential as distance between grid cells $(R)$ increases

\begin{tabular}{lrrrrrrrrrrrr}
\hline & $R=0$ & & $R=1$ & $R=2$ & $R=3$ & $R=4$ & $R=5$ & $R=6$ & $R=7$ & $R=8$ & $R=9$ \\
\hline$G_{a}=1.0$ & & 1 & 0.4 & 0.1 & 0 & 0 & 0 & 0 & 0 & 0 & 0 \\
$G_{a}=2.0$ & & 1 & 0.6 & 0.4 & 0.2 & 0.1 & 0.1 & 0 & 0 & 0 & 0 \\
$G_{a}=4.0$ & & 1 & 0.8 & 0.6 & 0.5 & 0.4 & 0.3 & 0.2 & 0.2 & 0.1 & 0.1 \\
$G_{a}=9.0$ & & 1 & 0.9 & 0.8 & 0.7 & 0.6 & 0.6 & 0.5 & 0.5 & 0.4 & 0.4 \\
\hline
\end{tabular}

Note: Values relative to 1.0, the absorption potential for a self-referential grid cell

Figure 5 shows the distribution of the sum of the probability density function $\mathrm{f}$ (calculated between all grid cells) in the model-island.

When the CAC was 0.003 , urban areas could not accumulate cereal and cereal shortages did not disappear. When the CAC was 0.03 , cereal shortages in urban areas disappeared. This behavior was the same as that found in the non-market-type model. When the CAC was 0.1 , some cities started to collect a lot of cereal and cereal stocks in productive areas became stable at around 10 to 20 . When the CAC was 0.3 , all urban areas established huge cereal stocks. On both sides of the mountains, where both GDP and cereal production were low, cereal stocks almost completely disappeared (Figure 6).

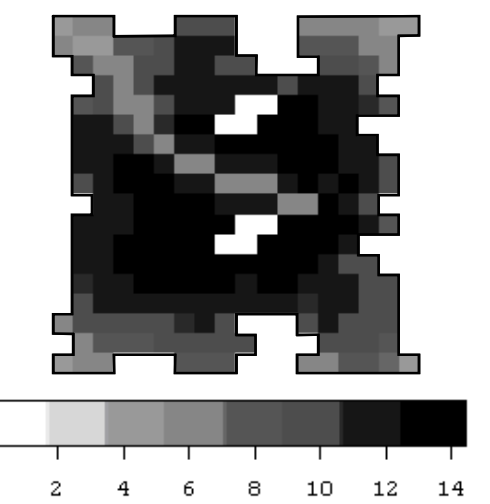

Figure 5. Distribution of the sum of the probability density function $f$ in a model-island
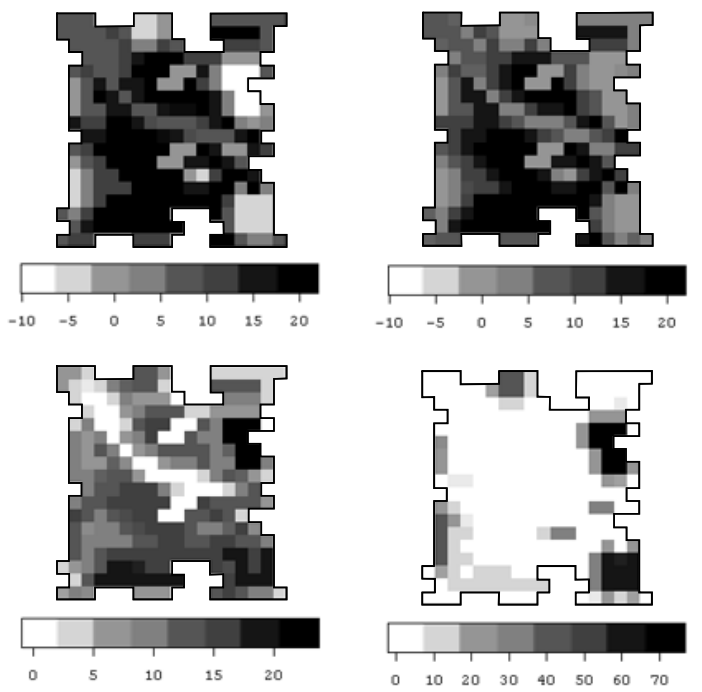

Figure 6. Cereal stocks in a model-island (Market-type model: at time-step 20)

Note: Cereal Absorption Coefficient: 0.003 (Upper left), Cereal Absorption Coefficient: 0.03 (Upper right), Cereal Absorption Coefficient: 0.1 (Lower left), Cereal Absorption Coefficient: 0.3 (Lower right). 


\subsection{Case Study in the Middle-south China}

The two models were applied to a region $2220 \mathrm{~km}$ by $2220 \mathrm{~km}$, covering the area from Shanghai to Kunming and Lanzhou (east-west), and from Guangzhou to Beijing (south-north). The authors compared the results at time-step 25. Although the marginal zone of the computed domain has some interaction with outside regions, it cannot be described here. Thus, our discussion on the results had to exclude the marginal zone of the inland side (Figure 7). Negative values were shown for the ocean and regions outside of China (including Chinese Taipei). Cereal consumption was assumed to be in proportion to the population (400 kg per year per capita). Population was concentrated in the coastal cities, the Sichuan basin, the North China Plain, and around Wuhan and Xi'an. Cereal was produced mainly around large cities (especially in the eastern region), the North China Plain, the Sichuan basin, Wuhan, Changsha, Nanchang, and Xi'an. In computing, the initial value of cereal stock was set to 0 .
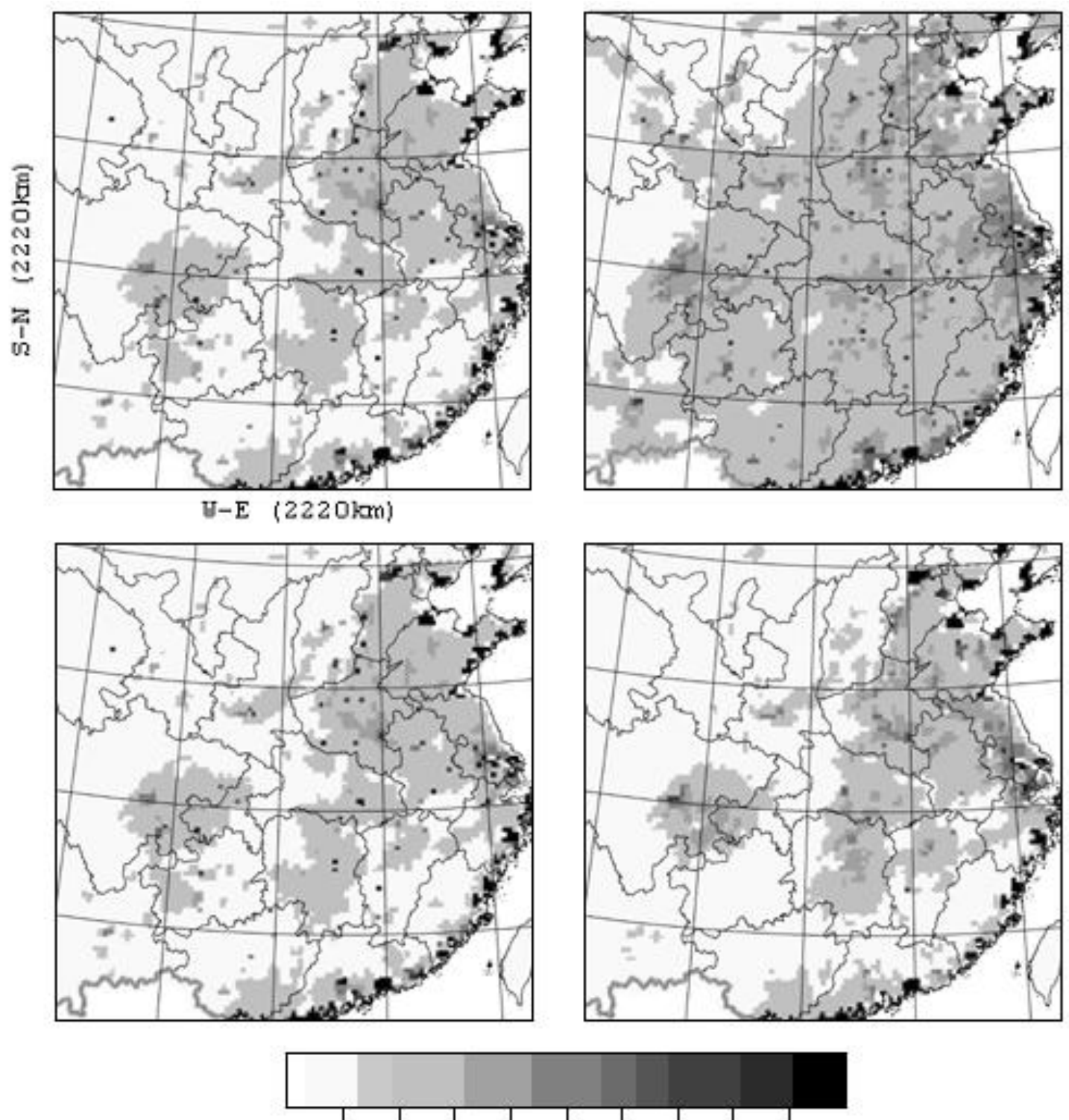

$\begin{array}{lllllllll}0 & 1 & 2 & 3 & 4 & 5 & 6 & 7 & 8\end{array}$

Figure 7. Population density (Upper left), GDP density (Upper right), cereal consumption (Lower left), and cereal production (Lower right) in the middle-south China, 10 grades

In the non-market-type model where there was no cereal transportation, Wuhan, Changsha, the Sichuan basin, Nanchang, eastern China, the Shandong peninsula, and the North China Plain accumulated cereal stocks, while cereal shortages occurred in the coastal cities, Chongqing, and the Yun-Gui Plateau. As the TIC increased, this imbalance disappeared, and at 0.005 no local imbalance could be observed (Figure 8). 

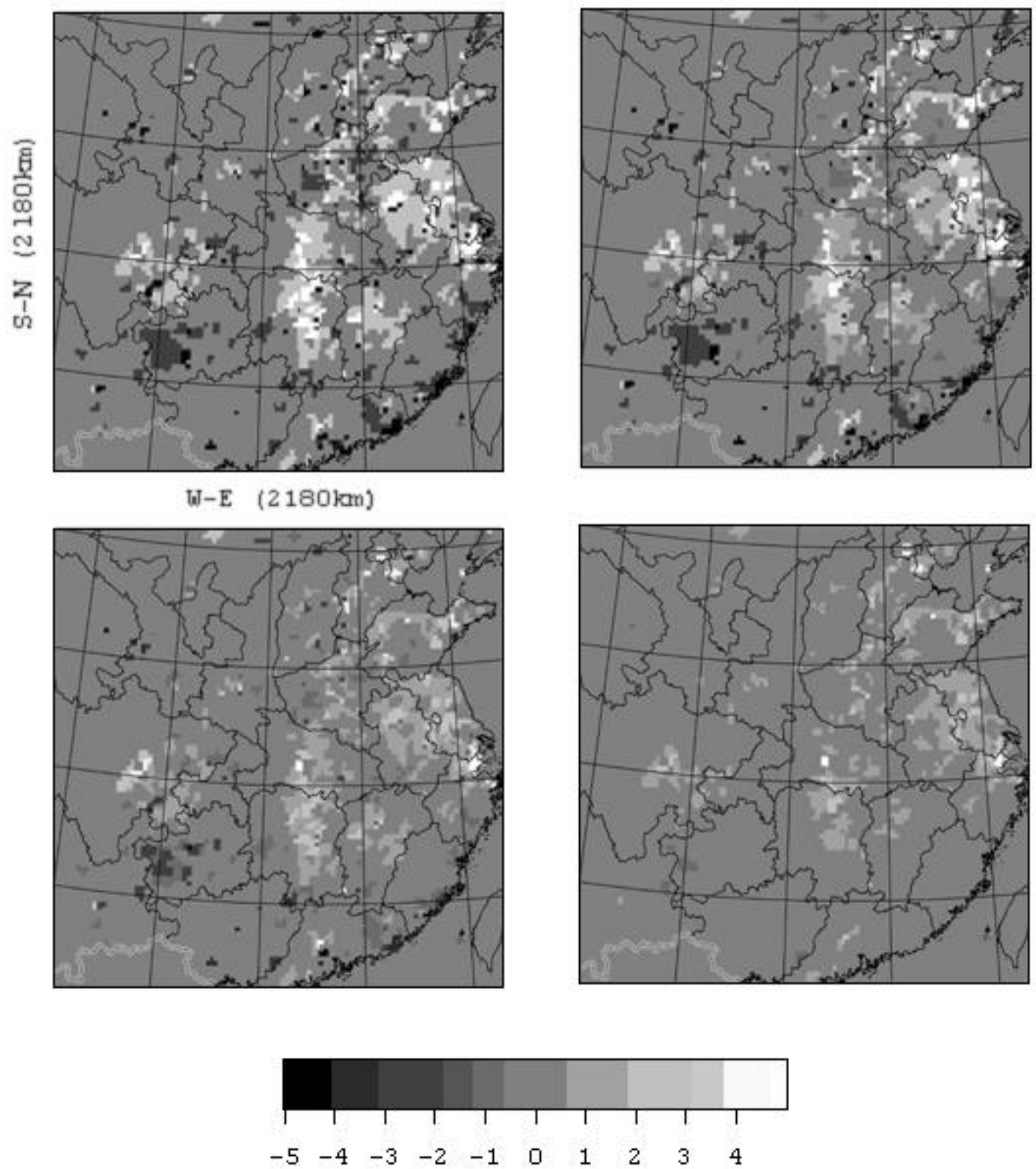

Figure 8. Cereal stocks in the middle-south China at time-step 25 (Non-market-type model)

Note: White areas indicate a value of $>5$; black areas indicate a value of $<-5$. The margin cells were not included in the computation. No transportation (Upper left), TIC: 0.0005 (Upper right), TIC: 0.001 (Lower left), TIC: 0.005 (Lower right).

In the market-type model, sensitivity of cereal absorption to distance between grid cells was set to a third that of the model-island due to the extent of the domain. As CAC increased, some coastal cities rapidly accumulated cereal stocks and an extended cereal crisis occurred in the inland regions caused by decreasing cereal stocks in productive regions (Figure 9).

\section{Conclusion}

The authors established two cereal transportation models, a non-market type and a market type, and performed numerical simulations on the temporal and spatial variability of cereal stocks on a pseudo island and in the middle-south China. In the case of no cereal transportation, severe cereal shortages occurred in urban regions. In the non-market-type model, cereal shortages gradually disappeared in urban regions as TIC increased, and cereal stocks in productive regions also decreased. Therefore, the local imbalances disappeared. In the market-type model, on the other hand, cereal stocks accumulated rapidly in coastal urban regions as the CAC increased. Although the decrease in cereal stocks in productive areas was slightly delayed, a spatial imbalance due to cereal shortages in the inland regions appeared. The disappearance 
of the imbalance over time as was shown in the non-market-type model did not appear.
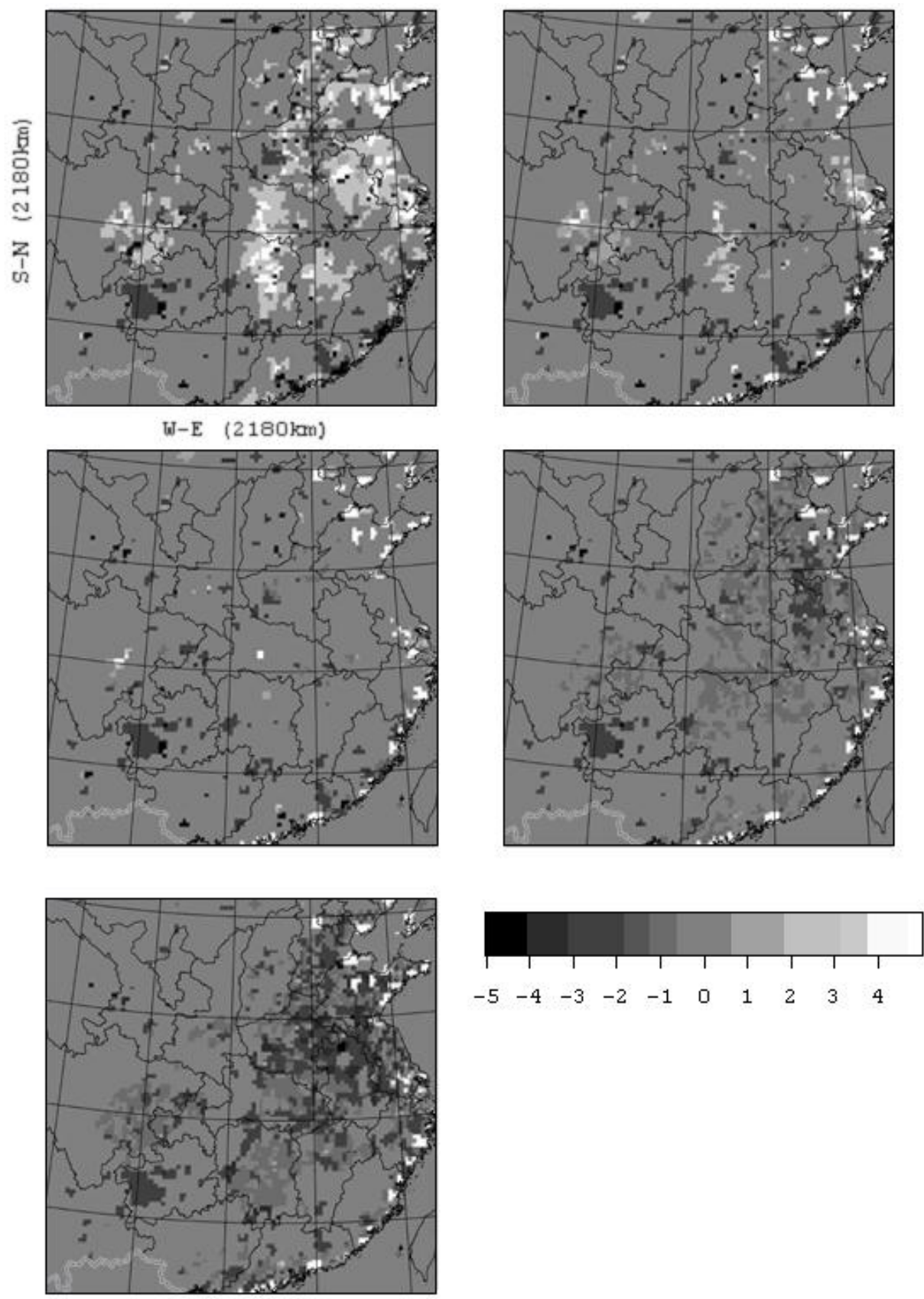

Figure 9. Cereal stocks in the middle-south China at time-step 25 (Market-type model)

Note: White areas indicate a value of $>5$; black areas indicate a value of $<-5$. The margin cells were not included in the computation. CAC: 0.01 (Upper left), CAC: 0.05 (Upper right), CAC: 0.1 (Middle left), CAC: 0.5 (Middle right), CAC: 1.0 (Lower left).

\section{Acknowledgements}

The authors show his special thanks to Prof. Dr. Kuninori Otsubo (Sophia University) and Dr. Qinxue Wang (National Institute for Environmental Studies) for their appropriate advices. All data for this paper is properly cited and referred to in the reference list.

\section{References}

Brown, L. R. (1995). Who Will Feed China? Wake-up Call for a Small Planet. New York: W.W. Norton.

Grebitus, C., Lusk, J. L., \& Nayga, Jr. R. M. (2013). Effect of distance of transportation on willingness to pay for food. 
Ecological Economics, 88, 67-75. https://doi.org/10.1016/j.ecolecon.2013.01.006

Otsubo, K., Wang, Q., Nakaya, T., Shimizu, Y., Bito, A., Ichinose, T., \& Kondo A. (2002). 20-km grid analysis on current and future situations on food balance in mainland China. In K. Otsubo (Ed.), LU/GEC Project Report IIX (Study on the processes and impact of land-use change in China -Final report of the LU/GEC second phase (1998-2000)-), CGER-Report (pp. 17-33). CGER-I053-2002 (ISSN 1341-4356).

Sirieix, L., Grolleau, G., \& Schaer, B. (2008). Do consumers care about food miles? An empirical analysis in France. International Journal of Consumer Studies, 32, 508-515. https://doi.org/10.1111/j.1470-6431.2008.00711.x

Vanek, F., \& Sun, Y. (2008). Transportation versus perishability in life cycle energy consumption: A case study of the temperature-controlled food product supply chain. Transportation Research Part D, 13, 383-391. https://doi.org/10.1016/j.trd.2008.07.001

Wang, Q., Otsubo, K., \& Ichinose, T. (2002). Estimation of potential and convertible arable land in China determined by natural conditions. Journal of Global Environment Engineering, 8, 67-78. https://www.jsce.or.jp/library/open/proc/maglist2/00771/2002/mg01.htm

Xiao, P., \& Wang, Q. (1999). Changes in grain production in China since 1949 and major reasons [in Japanese with English Abstract]. Geographical Review of Japan, 72A, 589-599. https://doi.org/10.4157/grj1984a.72.9_589

Xiao, P. (1997). The cultivated land change and its impacts on grain production in China. Annals of the Hokkaido Geographical Society, 71, 23-31.

Zepeda, L., \& Deal, D. (2009). Organic and local food consumer behavior: alphabet theory. International Journal of Consumer Studies, 33, 697-705. https://doi.org/10.1111/j.1470-6431.2009.00814.x

Zhang, L. C. (2000). Food distribution change in China and its reasons [in Chinese]. Resource and Environment in the Yangtze Basin, 9(2), 221-228.

\section{Copyrights}

Copyright for this article is retained by the author(s), with first publication rights granted to the journal.

This is an open-access article distributed under the terms and conditions of the Creative Commons Attribution license which permits unrestricted use, distribution, and reproduction in any medium, provided the original work is properly cited. 